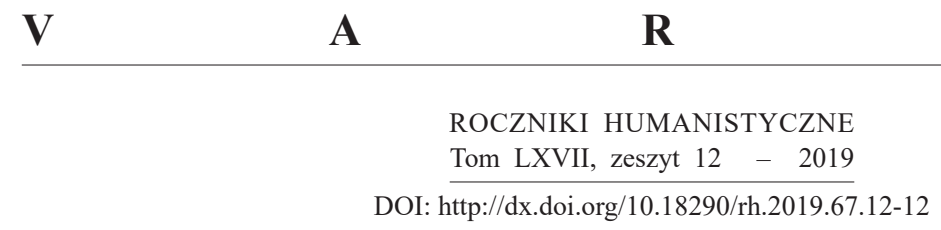

KINGA KRZYMOWSKA-SZACOŃ

\title{
ELEMENTY KONSTRUKTYWISTYCZNE W TWÓRCZOŚCI IANNISA XENAKISA (1922-2001)
}

\section{KONSTRUKTYWIZM W MUZYCE}

Termin „konstruktywizm” występuje w teorii muzyki dość rzadko i zazwyczaj w znaczeniu uogólnionym, oznaczając dążenie do uzyskania funkcjonalnej, celowej i racjonalnej konstrukcji dźwiękowej. Tak rozumiane pojęcie odnoszone bywa do motetów renesansowych, a także twórczości J.S. Bacha, czy - współcześnie - H.M. Góreckiego i A. Panufnika ${ }^{1}$. Pogłębione studia wskazują jednak, że konstruktywizm w muzyce można rozumieć nie tylko jako ogólną zasadę kształtowania formy zgodnie ze ściśle określoną logiką konstrukcji, ale także jako estetyczną analogię do nurtu artystycznego o tej samej nazwie, który rozwinął się w Rosji na początku XX wieku².

Aby zrozumieć genezę konstruktywizmu, należy wziąć pod uwagę zarówno dekadenckie nastroje przełomu XIX i XX w., jak i specyficzną sytuację ówczesnej

Dr Kinga KrZYMowsKa-Szacoń - Instytut Nauk o Sztuce, Katolicki Uniwersytet Lubelski Jana Pawła II; e-mail: kinga.krzymowska@gmail.com

Kinga Krzymowska-Szacoń - The John Paul II Catholic University of Lublin; e-mail address: kinga.krzymowska@gmail.com

${ }^{1}$ Por. K. Droba, Górecki Henryk Mikołaj, w: E. DzIĘBowsKa (red.), Encyklopedia muzyczna PWM, t. efg, Kraków 1986, s. 424, E. SiemdaJ, Andrzej Panufnik. Twórczość symfoniczna, Kraków 2003, s. 313.

${ }^{2}$ Artykuł przytacza tezy opisane szerzej w pracy magisterskiej (K. KRZYMOwSKA-SzaCoŃ, Konstruktywizm w twórczości Iannisa Xenakisa, mps pracy magisterskiej napisanej pod kierunkiem dr hab. Barbary Gogol-Drożniakiewicz, prof. KUL, Lublin 2009), uzupełnione o późniejsze badania i zarysowaną pokrótce refleksję z zakresu estetyki. 
Rosji, w której na podatny grunt trafiały zarówno postulaty rewolucyjne, jak i śmiałe europejskie nurty awangardowe. Spośród tych ostatnich kluczową rolę w formułowaniu założeń konstruktywizmu odegrały: włoski futuryzm, który obalając zastany porządek zwracał się w kierunku nowoczesnej cywilizacji przemysłowej i dynamicznego rozwoju technologii oraz kubizm, którego przedstawiciele zakładali, że istotę dzieła sztuki odnaleźć można nie tyle w jego formie, co w prawidłowościach budowy.

Za symboliczny początek konstruktywizmu uznaje się rok 1913, w którym odbyła się premiera opery Michaiła Matiuszyna Zwycięstwo nad słońcem ${ }^{3}$. Nieco później Włodzimierz Tatlin ${ }^{4}$ zaprezentował swoje Reliefy. Zestawione z trójwymiarowych materiałów dzieła nie tylko przekraczały tradycyjną płaszczyznę obra$\mathrm{zu}$, ale także były wolne od wszelkich przedmiotowych odniesień, według autora ukazując przede wszystkim prawdę materiatu, kolejne dzieła konstruktywistów, zrywając z typowymi dla malarstwa technikami, również zacierały granice między poszczególnymi typami sztuki. Interdyscyplinarność, brak odniesień do świata rzeczywistego (sztuka nieprzedstawiająca) oraz wyjście poza dwuwymiarową przestrzeń malarską stały się odtąd charakterystyczne dla konstruktywizmu, podobnie jak funkcjonalność, ścisłe obliczanie konstrukcji oraz sięganie do nowoczesnych technologii. Znaczący wpływ na rozwój nurtu mieli Aleksander Rodczenko (18911956) i Aleksiej Gan (1883-1942), którzy w 1920 r. założyli Pierwsza Robocza Grupę Konstruktywistów. Dwa lata później A. Gan opublikował manifest, w którym wezwał artystów do poniechania tej działalności spekulatywnej, jaką miało być tworzenie obrazów i przystosowania zdrowych baz sztuki - kolorów, linii, form, materiatów - do realnego dziatania, do konstrukcji $i^{5}$.

Utrzymując powyższe założenia, przez analogię zdefiniować można styl konstruktywistyczny dla sztuki muzycznej. Podstawowym problemem konstruktywizmu muzycznego byłoby więc nie tyle zagadnienie formy, co budowy dzieła - kompozycja jest tu utożsamiana z konstrukcją, rozumianą jednak nie jako szablon, lecz jako proces, podlegający przemianom i udoskonaleniom. Wynika stąd akcentowanie aspektu materiałowego oraz ukierunkowanie na nowatorskie rozwiązania $w$ tej dziedzinie, zazwyczaj inspirowane sztuką, nauką bądź życiem codziennym. Co więcej, nie tylko materiał buduje dzieło sztuki, lecz także sama zasada, w myśl której ksztat-

${ }^{3}$ Z librettem Aleksieja Kruchonycha (1886-1968), pisarza, twórcy tzw. języka pozarozumowego wykorzystanego m.in. w wyżej wymienionej operze. Michaił Matiuszyn (1861-1934) był rosyjskim malarzem, skrzypkiem i kompozytorem związanym z nurtem futurystycznym.

${ }^{4}$ Włodzimierz Tatlin (1885-1953) - rosyjski malarz i architekt, jeden z prekursorów konstruktywizmu, swoją karierę rozpoczynał jako ikonopis.

${ }^{5}$ A. Gan, Konstruktywizm, cyt. za: E. DolowsKa, Konstruktywizm rosyjski, „Wielcy Malarze. Ich Życie, Inspiracje i Dzieło" 2001, nr 131, s. 5. 
ty sa powiqzane 6 . W muzyce konstruktywistycznej proces tworzenia oparty jest więc na ściśle określonych założeniach, wyprowadzonych z nauk ścisłych (przede wszystkim z matematyki), a realizowanych często za pomocą nowoczesnej technologii. Dzieło konstruktywistyczne wykracza poza wyznaczone tradycją granice sztuki muzycznej, dążąc w kierunku interdyscyplinarności, a zwłaszcza powiązania $\mathrm{z}$ architekturą, w której konstrukcja odgrywa główną rolę. Ponadto, podobnie jak konstruktywistyczne malarstwo przekracza ramy obrazu, muzyka także staje się przestrzenna, a jej dźwięki otaczają słuchaczy. Żadne z dzieł nie przedstawia jednak rzeczywistości w sposób bezpośredni, jego bezprzedmiotowość ma bowiem skupiać uwagę odbiorcy na czystej sztuce?

\section{CECHY KONSTRUKTYWISTYCZNE W TWÓRCZOŚCI IANNISA XENAKISA}

Wymienione wyżej elementy zauważyć można w twórczości Iannisa Xenakisa (1922-2001), greckiego kompozytora i architekta, który z powodów politycznych ${ }^{8}$ podjął decyzję o emigracji. Po II wojnie światowej znalazł się w Paryżu, gdzie rozpoczął działalność kompozytorską. Jego wczesna twórczość spotkała się zarówno z ostrą krytyką (Artur Honegger i Dariusz Milhaud odnieśli się do utworów młodego inżyniera ze sceptycyzmem; Honegger odmówił im nawet prawa do określenia mianem muzyki ${ }^{9}$ ), jak i wyrazami uznania (Xenakis stał się uczniem, a później także przyjacielem Oliviera Messiaena). We Francji artysta zetknął się bezpośrednio z konstruktywizmem rosyjskim - przede wszystkim za sprawą wieloletniej współpracy z Le Corbusierem, uznawanym za pioniera tego ruchu w architekturze zachodniej, a także dzięki zainteresowaniu poezją konstruktywistów, do której w późniejszych latach tworzył muzykę ${ }^{10}$.

Iannis Xenakis opracował indywidualną technikę kompozytorską, która wywarła znaczący wpływ na rozwój awangardy oraz muzyki elektroakustycznej w II połowie XX w. Poniżej zostaną opisane pokrótce jej założenia, uwzględniając przy tym analogie do konstruktywizmu.

\footnotetext{
${ }^{6}$ A. Turowski, Budowniczowie świata: Z dziejów radykalnego modernizmu w sztuce polskiej, Kraków 2000, s. 90.

${ }^{7}$ K. KrZYMowsKa-Szacoń, Constructivism in the Works of Iannis Xenakis as a New Link between Avant-garde Art and Music, http://btc.web.auth.gr/_assets/_papers/krzymowska.pdf [28.08.2019], s. 2-3.

${ }^{8}$ Za działalność w komunistycznym Narodowym Froncie Wyzwolenia groziła mu kara śmierci.

${ }^{9}$ B.A. VARGA, Conversation with Iannis Xenakis, London 1996, s. 27.

${ }^{10}$ Między innymi do Trois poèmes Włodzimierza Majakowskiego (1893-1930).
} 


\section{a) Zerwanie z tradycja}

Awangarda odkrywa nowe światy, zamiast kurczowo trzymać się starych ${ }^{11}$, burzy schematy, nieustannie poszukuje, odrzuca tradycję, opiera się na innych zasadach bądź czyni zasadą ich brak ${ }^{12}$. Konstruktywiści postulowali nowy porządek świata, a co za tym idzie, także i sztuki. Analogiczne zjawisko miało miejsce w twórczości Xenakisa, który przekroczył nie tylko ramy XIX-wiecznej harmoniki czy tradycyjnych form muzycznych, ale także dodekafonii i serializmu, a więc wiodących nurtów awangardowych ${ }^{13}$. Kompozytor tworzył materiał ze złożonych, niezwykle zróżnicowanych mas dźwiękowych ${ }^{14}$, a determinację serii zastąpił indeterminizmem. Nie był to jednak charakterystyczny dla II awangardy aleatoryzm, lecz oparta na matematycznej teorii rachunku prawdopodobieństwa muzyka stochastyczna ${ }^{15}$. Artysta wprowadził powyższą nazwę w 1956 r., określając w ten sposób swoje eksperymentalne kompozycje wykorzystujące prawa stochastyki ${ }^{16}$. Jak sam twierdził, prawidła rachunku prawdopodobieństwa weszły w skład kompozycji przez koniecznośćc ${ }^{17}$.

${ }^{11}$ Z. BARAnowicz, Polska awangarda artystyczna 1918-1939, Warszawa 1975, s. 5.

${ }^{12} \mathrm{~K}$. KrzymowsKa-Szacoń, Constructivism in the works, s. 4.

${ }^{13} \mathrm{~W}$ artykule zatytułowanym La crise de la musique serielle (Kryzys muzyki serialnej) Xenakis stwierdził, że w serializmie polifonia linearna niszczy sama siebie przez swoją ogromną złożoność, mimo ścisłych założeń nie tworząc nic więcej, jak tylko masy dźwięków irracjonalnie rozmieszczonych w różnych rejestrach. I. XENAKIs, La crise de la musique sérielle, „Gravesaner Blätter” $1955, \mathrm{nr} 1$.

${ }^{14}$ Warto podkreślić innowacyjność tego rozwiązania, bowiem tworzenie nowego materiału muzycznego stało się charakterystyczne dopiero dla muzyki elektronicznej.

${ }^{15} \mathrm{Z}$ gr. stochos - cel; Cage'owski aleatoryzm uważał Xenakis za nadużycie języka muzycznego i swoiste unieważnienie funkcji kompozytora (por. M. BoIs, Iannis Xenakis. The Man and his Music: A Conversation with the Composer and a Description of his Works, Westport 1980, s. 12). Zapytany, dlaczego w swoich dziełach unika przypadkowych dźwięków odpowiedział, że wszyscy znamy takie dźwięki z naszego codziennego życia, sq one banalne $i$ nudne. Zaznaczył przy tym, iż nie jest zainteresowany reprodukcja banałów (K.-W. Choong, Iannis Xenakis and Elliott Carter: A Detailed Examination and Comparative Study of Their Early Output and Creativity, Brisbane 1996, s. 32). Jego rozumienie przypadkowości w muzyce było bezprecedensowe, bowiem jako jedyny starał się on kontrolować przypadek na tyle, na ile tylko pozwalała ówczesna matematyka.

${ }^{16}$ Stochastyka - ogół teorii matematycznych służących do opisu zjawisk losowych.

${ }^{17}$ Jako przykład artysta wymienił zjawiska naturalne, takie jak zderzenie deszczu z twardą powierzchnią bądź letnie odgłosy cykad. Kompozytor dodał także, iż takie zjawiska dźwiękowe składaja się z tysięcy osobnych dźwięków, tworząc następnie plastyczna formę czasu, kierowaną regułami stochastycznymi. Jeżeli ktoś zażyczy stworzyć sobie z tego wielość nut, jak w strunowym pizzicato, musi znać stosowne reguły matematyczne, które nie sa niczym innym jak wyrazem ciagu logicznego, zwartego i treściwego myślenia [...]. I. Xenakis rozumiał powyższe zjawisko jako proces przejścia od całkowitego uporządkowania do totalnego rozbicia, zamieszania w narastajacy lub eksplozywny sposób. To reguły stochastyczne. Dotykamy tu jednego z wielkich problemów, który pochłaniał ludzka 
Wspomniana problematyka pojawiła się już w jednym z pierwszych dzieł Xenakisa, Metastaseis (1953-1954) i była rozwijana podczas pracy nad Pithoprakta (1955-1956). Kompozytor zorganizował wówczas materiał muzyczny wykorzystując kinetyczną teorię dotyczącą temperatury gazów, tworząc analogię między ruchem cząsteczek gazu a zmianą wysokości dźwięków. Sam materiał w każdym z utworów był jednak otrzymywany inaczej: Metastaseis oparte zostało na dodekafonii, uporządkowanej za pomocą ciągu Fibonacciego, podczas gdy w Pithoprakta poszczególne dźwięki określone zostały przez Prawo Wielkich Liczb Bernoullie$\mathrm{go}^{18}$. Rzecz jasna, aby zastosować w procesie kompozycji jakikolwiek wzór, Xenakis musiał „rozbić” pojedyncze dźwięki na szereg charakteryzujących je wartości mierzalnych, takich jak wysokość, czas trwania, natężenie czy gęstość ${ }^{19}$.

Efekty takiego działania kompozytor nazwał wolna muzyka stochastyczna. Jej założenia kształtują się następująco: ruch w wymiarze mikroskopowym (w dziełach orkiestrowych reprezentowanych przez pojedyncze instrumenty) podlega wymiarowi makroskopowemu. Gęsta struktura, nazwana przez kompozytora chmurami lub galaktykami dźwięków, posiada tak wiele składowych, że zamiast określać indywidualne ich zachowania, wyznacza się efekt całościowy. W ten sposób powstało m.in. Achorripsis (z gr. Strumienie dźwięku, 1957) na orkiestrę kameralną złożoną z 21. muzyków, podzieloną na siedem grup ${ }^{20}$. Aby uporządkować gęstość brzmienia, kompozytor zastosował różne rodzaje rozkładów (Poissona, wykładniczy, liniowy i normalny $)^{21}$. Elementy muzyki stochastycznej kompozytor stosował w większości

inteligencję od antyku. I. Xenakis, Formalized Music: Thought and Mathematics in Music, New York 1992, s. 9.

${ }^{18}$ Jedno z praw charakteryzujących związek pomiędzy częstością względną pewnego zdarzenia losowego (tzn. ilością jego faktycznych wystąpień w danej próbie losowej) a prawdopodobieństwem jego wystąpienia uogólnionym na dużą liczbę powtórzeń danego doświadczenia.

${ }^{19}$ Xenakis uznawał za niemierzalną jedynie barwę dźwięku.

${ }^{20}$ Premiera dzieła, która odbyła się w 1958 roku w Buenos Aires pod dyrekcją ceniącego twórczość Xenakisa H. Scherchena, została odebrana pozytywnie. Kolejne, europejskie wykonania nie cieszyły się uznaniem publiczności (przyzwyczajonej do zupełnie innej muzyki), aż do 1965 r., kiedy utwór został przedstawiony na festiwalu dzieł Xenakisa w Paryżu. Jednak nawet w kolejnych latach zarzucano Achorripsis bezosobowy charakter (T.A. Zieliński).

${ }^{21} \mathrm{~W}$ rozkładzie Poissona $\left(P_{k}=\frac{\lambda^{k}}{k !} e^{-\lambda}\right)$, zastosowanym na poziomie makroskopowym, $k=0,1,2, \ldots$ oznacza numer zdarzenia, $P_{k}$ rozumiemy jako prawdopodobieństwo wystąpienia zdarzenia $k$, zaś $e$ jest liczbą stałą. Przykładowo, chcąc obliczyć prawdopodobieństwo, że nie wystąpi żadne zdarzenie dźwiękowe (co jest tożsame z pauzą), należy podstawić k=0. Wówczas $P_{0}=\frac{0,6^{0}}{0 !} e^{-0,6}=0,5488$, a więc prawdopodobieństwo wystąpienia w danej komórce pauzy wynosi ponad 1/2. Kontynuując obliczenia łatwo spostrzec, że pauzy wystąpią w 196 x 0,5488 = 107 komórkach. Na poziomie mikroskopowym 
swoich późniejszych dzieł, m.in. w Hermie na fortepian (1960-1963), elektroakustycznym balecie Kraanerg (1968-1969) 22 .

Xenakis twierdził, że nauka, a szczególnie stochastyka może prowadzić do stworzenia nowego materiatu dźwiękowego i nowych form ${ }^{23}$. W hipotezie tej odnaleźć można analogię do założeń konstruktywistów, według których budowanie nowych, awangardowych dzieł sztuki jest tożsame ze sprowadzaniem chaosu do porzadku i zmuszaniem dowolności do tadu ${ }^{24}$.

\section{b) Elementy sztuki „nieprzedstawiajacej”}

Cel działalności artystycznej konstruktywistów stanowiła realna budowa, konstrukcja. W swoich manifestach stawiali oni prowokujące pytania: Po co odzwierciedlać życie, skoro mamy je do swojej dyspozycji? Kto wolatby kopię od oryginatu? Artysta odbija życie na swój sposób. To jeszcze gorsze. Można powiedzieć, że je deformuje ${ }^{25}$. Typowa dla konstruktywistów idea nieprzedstawiania znalazła swoje odzwierciedlenie przede wszystkim we wczesnych utworach I. Xenakisa, charakteryzujących się zanikiem czynnika melodycznego na rzecz rozwoju faktury za pomocą częstego glissando oraz rozbudowanych klasterów, odpowiadających konstruktywistycznym liniom prostym oraz geometrycznym krzywym, które miały uwolnić dzieła sztuki od balastu przedstawiania ${ }^{26}$.

Osobny, interesujący aspekt owej bezprzedmiotowości stanowią utwory wokalne bądź wokalno-instrumentalne, których tekst oparty został na nieprzedstawiajacych głoskach (fonemach) ${ }^{27}$. Warto podkreślić, że rezygnacja z charakteru mimetycznego

kompozytor zastosował trzy rodzaje rozkładów: wykładniczy dla określenia odległości pomiędzy zdarzeniami, liniowy (wyznaczający interwały początkowe) i normalny (rozkład partii glissando).

${ }^{22} \mathrm{~W}$ pierwszym $\mathrm{z}$ wymienionych utworów reguły probabilistyczne znalazły zastosowanie w procesie wyboru kolejności oraz rytmu poszczególnych nut, zaś w drugim dookreśliły podział na odcinki orkiestrowe oraz fragmenty na taśmę. W innych dziełach, takich jak Diamorphoses (1958) czy Concret PH (1958), Xenakis stosował m.in. Łańcuchy Markowa (procesy, w których prawdopodobieństwo danego zdarzenia zależy wyłącznie od stanu w chwili poprzedniej).

${ }^{23}$ I. Xenakis, Formalized Music, s. 43.

${ }^{24}$ T. PeIPER w: A. Turowski, Między sztuka a komuna, Kraków 1998, s. 58. W założeniach konstruktywistów czytamy, że lepiej z zawiązanymi oczami rzucić paleta w płótno, walić pięściami albo siekiera w glinę czy marmur, usiasśc na klawiaturze - niż pozostawać, ślepo i bezdusznie, niewolnikiem wyświechtanego szablonu. W pierwszej sytuacji być może przypadek, mimo woli, stworzy żywa istote, a żywa mysz jest zawsze lepsza od martwego lwa (A. Turowski, Między sztuka a komuna, s. 215).

${ }^{25}$ O. BRIK, cyt. za: http://Fusionner-l-art-et-la-vie-I.html [28.08.2019].

${ }^{26}$ A. Wiesnin za: A. Turowski, Między sztuka a komuna, s. 356.

${ }^{27}$ Bezznaczeniowe głoski przywodzą na myśl wspomniany już język pozarozumowy A. Kruczonycha, w którym powstał tekst pierwszej opery konstruktywistycznej. 
dotyczy tutaj warstwy tekstowej, która w muzyce jest zazwyczaj czynnikiem niosącym treść. Przykładem mogą być Nuits (Noce, 1967), pierwszy utwór chóralny Xenakisa, dedykowany nieznanym więźniom politycznym. Na jego tekst składają się sumeryjskie, asyryjskie i achajskie fonemy, co powoduje, że słuchacze zwracają większą uwagę na czysty dźwięk, niezwiązany z konkretną treścią. Podobnie odbiorcy bezprzedmiotowego malarstwa odbierają jedynie samo dzieło, w nim, a nie w tym, co przedstawia, odnajdując treść.

\section{c) Nowy materiat konstrukcyjny}

Zagadnienie materiału zajmuje w rozważaniach konstruktywistów miejsce szczególne ${ }^{28}$. Problematyka ta widoczna jest także w twórczości I. Xenakisa, który jako architekt uznawał nadrzędną rolę materiału w procesie konstrukcyjnym. Poszukując nowych rozwiązań w tym zakresie, wypracował on ideę muzyki symbolicznej, opartej na algebrze i analizie matematycznej. Poszczególne elementy dzieła muzycznego zostały tutaj podporządkowane konkretnym zmiennym, co umożliwiło wykorzystanie ich w regułach algebraicznych. Otrzymane za pomocą praw matematyki zbiory wartości istnieją niezależnie od charakterystycznego dla skal muzycznych uporządkowania dźwięków, wyznaczającego swoiste zależności, takie jak relacje wobec dźwięku centralnego, czy rozwiązanie powstających napięć. Tego typu struktury „pozaczasowe” odnajdujemy w opracowanej przez Xenakisa teorii skal, które nazwał sitami ${ }^{29}$. Teoria ta została po raz pierwszy wykorzystana w Akrata

\footnotetext{
${ }^{28}$ Wystarczy wspomnieć W. Tatlina, twórcę zasady kultury materiałów, podkreślającego aspekt materiałowy swoich konstrukcji. Konstruktywiści wykorzystywali często w swoich pracach materiały nietypowe dla malarstwa, np. metal czy szkło. Organizowano też wystawy przedstawiające materiat jako taki i jego skutki - ruch, napięcie i ich wspótzależności (W. TaTLIN, za: A. Turowski, Między sztukq a komuna, s. 292).

${ }^{29}$ I. XenaKis, Formalized Music, s. 183-200. Teoria sit została ostatecznie sformułowana w połowie lat 60. Jak twierdził kompozytor, z nieskończonej ilości wszystkich możliwych wysokości dźwięku wybierał tylko nieliczne, stąd nazwa „sito” (por. VARGA, Conversation, s. 94). Xenakis zaczerpnął inspirację z koncepcji Arystoksenosa oraz muzyki bizantyjskiej. Cały proces polegał na przyporządkowaniu poszczególnym wysokościom dźwięku konkretnych wartości liczbowych i porównaniu ich do ciągłej osi liczb rzeczywistych przy jednoczesnym zniesieniu podziałów oktawowych. Sita charakteryzowały się większą różnorodnością interwałów niż skale systemu funkcyjnego, tworząc i utrzymując napięcie dzięki przeciwstawianiu dużych i małych interwałów. Sito można rozumieć jako formułę wyboru punktów na osi wysokości bądź rytmu. Opiera się ono na parze liczb całkowitych, przy czym pierwszą z nich stanowi modulo $(\mathrm{m})$ wyznaczające pewną odległość, zaś druga, oznaczająca resztę pozostającą po podzieleniu elementów zbioru przez $m$, mieści się w przedziale domkniętym $<0, m-1>$. Pary te tworzą następnie tzw. klasy, które mogą podlegać dalszym przekształceniom, takim jak transpozycja, odnajdywanie dopełnienia zbioru bądź łączenie istniejących już grup i modyfikowanie ich za pomocą prostych działań na zbiorach.
} 
(1964-1965) na 16 instrumentów dętych drewnianych, zaś w pełni rozwinięta w Nomos Alpha (1966) na wiolonczelę ${ }^{30}$.

W tym ostatnim utworze występują także inne obiekty muzyczne, nazwane przez Xenakisa chmurami dźwiękowymi $i^{31}$. Składają się one ze stochastycznie wyznaczonych grup dźwięków, tworzących złożone zdarzenia ${ }^{32}$. W teorii opracowanej przez Xenakisa stanowią one podstawę materiału melodycznego odpowiadającą konstruktywistycznym szumom, uzyskiwanym przez obróbkę materiału.

\section{d) Interdyscyplinarność}

Konstruktywiści dążyli do scalenia sztuki, nauki i architektury. Ta ostatnia, ze względu na swój charakter, stanowiła w ich założeniach główne ogniwo. W twórczości Xenakisa, inżyniera i kompozytora zwanego architektem dźwięku (J. Harley), owo charakterystyczne przenikanie się sztuki i architektury uwidacznia się szczególnie we wczesnych dziełach, pochodzących z czasów współpracy z Le Corbusierem.

W 1954 r. Xenakis ukończył Metastaseis, w którym rola architektury jest bezpośrednia i fundamentalna ${ }^{33}$. W twórczości Xenakisa trudno byłoby znaleźć bardziej wyrazisty przykład interdyscyplinarności. Kompozytor kreślił strukturę Metastaseis (w tym charakterystyczne glissando) na papierze milimetrowym, zawierając w niej liczne rozwiązania stricte architektoniczne. W konsekwencji szkice utworu posłużyły później Xenakisowi do konstrukcji hiperboidalnej krzywizny ścian Pawilonu Philipsa, zaprezentowanego w 1958 r. na Wystawie Światowej w Brukseli.

W Metastaseis można ponadto wyodrębnić aspekt materiałowy, stanowiący wyraźne odbicie założeń konstruktywistycznych. Już sama formotwórcza rola glissando nasuwa skojarzenia z materiałem budowlanym. Ponadto kompozytor, opisując swoje dzieło, za materiał budowlany (odpowiednik cegły, kamienia, czy drewna) uznał również współbrzmienia orkiestry. Na interdyscyplinarny charakter dzieła wskazują elementy nauk ścisłych - zmianę barwy oraz dynamiki Xenakis dookre-

${ }^{30}$ Premiera dzieła, dedykowanego Arystoksenosowi z Tarentu, matematykowi i prekursorowi teorii muzyki, Évariste'owi Galois, który stworzył podwaliny teorii grup oraz kontynuatorowi jego idei, Feliksowi Kleinowi, odbyła się w 1966 r. w wykonaniu Siegfrieda Palma. Konstrukcja Nomos Alpha została z czasem rozszerzona na dzieło orkiestrowe pt. Nomos Gamma (1967-1968).

${ }^{31}$ Zob. I. Xenakis, Formalized Music, s. 31.

${ }^{32} \mathrm{~W}$ przypadku chmur, zwanych też przez kompozytora galaktykami, określenie czasu trwania poszczególnych dźwięków oraz ich wysokości za pomocą stochastyki miało naśladować pozornie przypadkowe zjawiska zachodzące w naturze, rządzące się jednak ściśle określonymi zasadami (dziś badane jako zjawisko chaosu).

${ }^{33}$ Le Corbusier, cyt. za: J. Harley, Xenakis: His Life in Music, New York 2004, s. 10. 
ślił w czasie za pomocą ciągu Fibonacciego. Co więcej, tytuł utworu wskazuje na wykorzystanie obecnej również w konstruktywizmie zasady kontrastów. Stanowi on bowiem połączenie greckich słów metá, oznaczającego poza, pod, wśród, obrazującego następstwo lub zmienność czegoś oraz stasis, czyli bezruch ${ }^{34}$.

Interdyscyplinarnością cechują się również Politopy, unikatowe spektakle światła, dźwięku i przestrzeni, które zostaną opisane bardziej szczegółowo w dalszej części artykułu.

\section{e) Porzucenie dwuwymiarowości}

Konstruktywiści uznawali, że w nowej sztuce dominować będzie nowe odczucie przestrzeni, która otacza wszystko swoją nieskończonością ${ }^{35}$. W konsekwencji porzucenie dwuwymiarowości stało się jednym z najważniejszych aspektów wczesnego malarstwa konstruktywistycznego, realizowanym m.in. przez Tatlina. Rozważając twórczość Xenakisa, powyższe założenie można rozpatrywać zarówno w kontekście wymienionych wyżej odniesień do architektury, jak i w aspekcie muzyki przestrzennej36. Przykładowo, wykonawcy Eonty (1963) rozmieszczeni są w różnych punktach estrady, $w$ głębi lub na przodzie, zmieniaja kierunek wylotów instrumentów, graja wprost na struny otwartego fortepianu lub spaceruja po estradzie ${ }^{37}$, co powoduje, że każda zmiana położenia wpływa na barwę oraz dynamikę dźwięku. Z kolei Concret PH (1958) na taśmę emitowane było z ponad 400 głośników znajdujących się w Pawilonie Philipsa na Wystawie Światowej w Brukseli w 1958 r. Przebieg utworu był ściśle związany z konstrukcją architektoniczną pawilonu, której Xenakis był współtwórcą. Konstruktywistycznemu dążeniu do „opuszczenia ram obrazu" odpowiada też koncepcja Terretektorh (1965-1966) na 88. muzyków rozproszonych wśród publiczności.

\footnotetext{
${ }^{34}$ Kompozycja rozpoczyna się cichym, zatrzymanym dźwiękiem, wypływającym jakby z pustki. Instrumenty smyczkowe wprowadzają wolne glissando, stopniowo zwiększając dynamikę, aż do kulminacyjnego w części początkowej współbrzmienia, którym jest gęsty klaster.

${ }^{35}$ M. Matiuszyn za: A. Turowski, Między sztuka a komuna, s. 140.

${ }^{36}$ Kompozycje przestrzenne były w XX w. pisane dość często. Już w 1927 r. A. Dymishitzskonstruował przestrzenny metalofon, którego zdalnie sterowane elementy miały być rozmieszczone wokół sali koncertowej. Eksperymenty dotyczące tego typu muzyki wyjaśniał Luigi Nono, twierdząc że tradycyjny skład orkiestry nie może odpowiadać współczesnym potrzebom. K. Stockhausen w komentarzu do partytury Fresco przedstawił wizję przyszłych rozwiązań architektonicznych, zdolnych sprostać wymaganiom nowej muzyki. I tak, w specjalnym domu muzyki miałyby znajdować się odpowiednio wyposażone pomieszczenia, korytarze, balkony, mosty, a nawet ruchome platformy.

${ }^{37}$ „Forum Musicum” 1970, nr 8, s. 75.
} 
Najpełniejszą realizację konstruktywistycznego założenia rozszerzenia wymiarów stanowią w twórczości Xenakisa Politopy ${ }^{38}$. W 1966 r., na Wystawie Światowej EXPO'67 w Montrealu, kompozytor zaprezentował multimedialny spektak1, zatytułowany Polytopes de Montréal ${ }^{39}$, który został wykorzystany w pokazywanym na wystawie Pawilonie Francuskim. W 1971 roku powstał Polytope de Persepolis, zamówiony przez szacha Iranu na otwarcie Festiwalu w Sziraz i wykonany w nietypowej scenerii, pomiędzy oświetlonymi rozproszonym światłem grobowcami władców dawnej Persji, Dariusza i Artakserksesa. W 1972 r. powstał jeszcze Polytope de Cluny, a w $1978^{40}$ - Le Diatope, dla którego kompozytor sam zaprojektował miejsce wykonania ${ }^{41}$. Elementem wspólnym wszystkich Politopów była tendencja do zburzenia bariery pomiędzy przestrzenią, widzem oraz samym dziełem - muzyka stawała się sztuka przestrzeni.

\section{f) Nowoczesne technologie}

Konstruktywiści podjęli koncepcję futurystów, postulujących organizację procesu tworzenia dzieł sztuki z wykorzystaniem nowoczesnych maszyn i technologii. Założenie to przeniknęło do wielu nurtów muzycznej awangardy, najbardziej rozpowszechniło się jednak w zakresie muzyki elektronicznej i komputerowej. Makis Solomos na podstawie zróżnicowania wykorzystanej technologii wyróżnia 4 okresy twórczości elektroakustycznej Xenakisa ${ }^{42}$. Do pierwszego z nich należą dzieła skomponowane w kierowanej przez Pierre'a Schaeffera Groupe de Recherches de Musique Concrète ${ }^{43}$ : m.in. Diamorphoses (1957), Concret PH (1958), czy Bohor (1962), Reprezentujący drugi okres Kraanaerg (1968) jest nie tylko elektroakustycznym baletem, ale także przykładem muzyki stochastycznej, którego zmienność zasadza się na dowolności wyboru między fragmentami zapisanymi na taśmie a tymi wykonywanymi przez tradycyjną orkiestrę. Kompozycje późniejsze, należące do trzeciego i czwartego okresu, takie jak Hibiki-Hana-Ma (1970) oraz S. 709 (1992) reprezentują odpowiednio muzykę komponowaną dla Politopów i dzieła

${ }^{38}$ Termin ,politop” pochodzi od greckich słów poly (liczny) oraz topos (miejsce), w geometrii zaś oznacza wielotop, czyli wielokąt, uogólniony na większą liczbę wymiarów.

${ }^{39}$ Budynek istnieje do dziś jako Casino de Montreal.

${ }^{40} \mathrm{Na}$ otwarcie Centrum Georges Pompidou w Paryżu.

${ }^{41}$ Był to specjalny namiot, który miał „podróżować” po całym świecie jako kulturalny i komercyjny ambasador Centrum Pompidou.

${ }^{42} \mathrm{M}$. Solomos, The unity of Xenakis' instrumental and electroacoustic music. The case of ,, brownian movements", "Perspectives of New Music" 39(2001), nr 1, s. 244-254.

${ }^{43}$ Grupa Badań Muzyki Konkretnej, od 1958 r. działająca jako Groupe de Recherches Musicales, czyli Grupa Badań Muzycznych. 
wykorzystujące algorytm dynamicznej syntezy stochastycznej (Xenakis stworzył program komputerowy przeznaczony do symulacji procesu komponowania, ST). W latach 1956-1962 powstały dzieła z serii ST, m.in. ST/4 na kwartet smyczkowy oraz $S T / 10$ na 10 instrumentów. Wszystkie te utwory wykorzystywały obliczeniową moc komputerów IBM dla określania instrumentacji, wysokości dźwięku, czasu jego trwania oraz dynamiki.

Pod koniec lat 60. Xenakis założył w okolicach Paryża EMAMu (Equipe de Mathematique et Automatique Musicales), przekształcone następnie w CEMAMu (Centre d'Etudes de Mathematique et Automatique Musicales ${ }^{44}$ ). Jest to centrum badawcze, w którym od 1978 r. powstawały wszystkie kompozycje elektroakustyczne Xenakisa. Obecnie służy ono kontynuatorom jego idei do prowadzenia dalszych badań w tej dziedzinie.

\section{PODSUMOWANIE}

Podsumowując przedstawione wyżej rozważania należy podkreślić, że mają one na celu nie tyle umieszczenie Iannisa Xenakisa w gronie konstruktywistów, co raczej wskazanie w jego stylu wyraźnych analogii do konstruktywizmu rosyjskiego. Zbieżność ta widoczna jest zarówno w zakresie idei, jak i techniki twórczej, co wydaje się szczególnie interesujące w kontekście estetyki sztuki XX w., z całą jej złożonością.

Jakie czynniki sprawiły, że w twórczości zachodnioeuropejskiego kompozytora zaistniały te same idee, które postulowali kilkadziesiąt lat wcześniej konstruktywiści rosyjscy (a później radzieccy)? Z pewnością brak akademickiego wykształcenia muzycznego mógł przełożyć się na swobodniejsze traktowanie zasad kompozycji, zaś wykształcenie w zakresie sztuk plastycznych wyznaczyć kierunek poszukiwań. Kluczowe wydają się jednak ideologiczne i estetyczne aspekty konstruktywizmu, kształtującego się w dużej mierze na bazie futuryzmu oraz nastrojów rewolucyjnych (anarchistycznych) i dążenia w kierunku socjalizmu. Wszystko to nieobce było także Xenakisowi, który w czasie II wojny światowej był członkiem komunistycznego ruchu oporu, zaś w kolejnych latach wspominał czytane w młodości manifesty socjalistyczne. Klamrą spinającą całość wydaje się w tym kontekście stojący u korzeni tzw. I awangardy muzycznej włoski futuryzm, z jego anarchizmem i fascynacją nowoczesnymi technologiami. Pogłębione badania nad tak przedstawioną problematyką wydają się być interesującym zagadnieniem z zakresu estetyki sztuki.

\footnotetext{
${ }^{44}$ Odpowiednio: Zespół Matematyki i Automatyki Muzycznej oraz Centrum Nauk Muzyki Matematycznej i Automatycznej.
} 


\section{BIBLIOGRAFIA}

BoIs M., Iannis Xenakis: The Man and his Music. A Conversation with the Composer and a Description of his Works, Westport 1980.

Arsenault L., Iannis Xenakis's Achorripsis: The Matrix Game, „Computer Music Journal” 26(2002), nr 1.

Droba K., Górecki Henryk Mikołaj, w: E. Dzięвowska (red.), Encyklopedia muzyczna PWM, t. efg, Kraków 1986, s. 420-433.

Exarchos D., Stamos I., Iannis Xenakis's Writing and Outside-Time Musical Structures, Thessaloniki 2008.

Fleuret M. (red.), Regars sur Iannis Xenakis, Paris 1981.

Harley J., Xenakis: His Life in Music, New York 2004.

Hoffmann P., Spatial Aspects in Xenakis' Instrumental Works, Athens 2005.

INGBERMAN S., ABC: international constructivist architecture, 1922-1939, Cambridge, 1994.

KrzymowsKa-Szacoń K., Constructivism in the Works of Iannis Xenakis as a New Link between Avant-garde Art and Music, http://btc.web.auth.gr/_assets/_papers/krzymowska.pdf [28.08.2019].

LODDer C., Russian Constructivism, London 1983.

Solomos M., The unity of Xenakis' instrumental and electroacoustic music. The case of ,, brownian movements", "Perspectives of New Music" 39(2001), nr 1, s. 244-254.

ToŁŁoczko Z., ToŁŁoczко T., W kręgu architektury konstruktywistycznej, neokonstruktywistycznej i dekonstruktywistycznej, Kraków 1999.

Turowski A., Między sztuka a komuna, Kraków 1998.

Turowski A., Budowniczowie świata: Z dziejów radykalnego modernizmu w sztuce polskiej, Kraków 2000.

VArga B.A., Conversation with Iannis Xenakis, London 1996.

Xenakis I., Formalized Music: Thought and Mathematics in Music, New York 1992.

Xenakis I., La crise de la musique sérielle, „Gravesaner Blätter” 1955, $\mathrm{nr} 1$.

Xenakis I., Le Corbusier, The Monastery of La Tourette, Princeton 1987.

http://Fusionner-l-art-et-la-vie-I.html [28.08.2019].

\section{ELEMENTY KONSTRUKTYWISTYCZNE W TWÓRCZOŚCI IANNISA XENAKISA (1922-2001)}

Streszczenie

Iannis Xenakis (1922-2001) był kompozytorem nietuzinkowym. Zamiast studiów w konserwatorium muzycznym wybrał Politechnikę Narodową w Atenach. Zamiast przepisywać fugi J.S. Bacha, kreślił na papierze milimetrowym innowacyjne szkice architektoniczne. Milan Kundera nazwał go prorokiem bezuczuciowości, zaś Artur Honegger odmówił jego próbom kompozytorskim miana muzyki. W środowisku drugiej awangardy Xenakis zyskał sobie jednak niekwestionowaną, wiodącą pozycję za sprawą innowacyjnych technik kompozytorskich, opartych zarówno na regułach matematycznych (probabilistyka, teoria zbiorów i in.), jak i na kształtującej się wówczas technologii informacyjnej. Prezentowany artykuł ukazuje twórczość artysty w odniesieniu do założeń rosyjskiego konstruktywizmu - nurtu, który, choć rozwinął się w innym środowisku, okazał się jednak zaskakująco zbieżny z stylem Xenakisa, ukazując pewne uniwersalne tendencje w XX-wiecznej sztuce awangardowej.

Słowa kluczowe: konstruktywizm; Iannis Xenakis; awangarda muzyczna. 


\section{ELEMENTS OF CONSTRUCTIVISM \\ IN THE WORKS OF IANNIS XENAKIS (1922-2001)}

\section{Sum mary}

Iannis Xenakis (1922-2001) was an extraordinary composer. Instead of studying at the music conservatory, he chose the National Technical University of Athens. Rather than rewriting J.S. Bach's fugues, he drew innovative architectural sketches on the plotting paper. Milan Kundera called him a prophet of insensitivity, while Arthur Honegger claimed that his works could not be described as music. In the second avant-garde, however, Xenakis gained an unquestionable, leading position due to his innovative compositional techniques, based both on mathematical principles (probabilistic, set theory etc.) and the information technology that was being developed at that time. The presented article describes the artist's work in relation to the foundations of Russian constructivism a trend that developed in a different environment, but nevertheless proved to be surprisingly convergent with the ideas of Xenakis, showing some universal tendencies in the 20th-century avant-garde art.

Key words: constructivism; Iannis Xenakis; musical avant-garde. 